\title{
Gadolinyuma Bağlı Akut Böbrek Hasarı: Bir Olgu Sunumu
}

\author{
Gadolinium Induced Acute Renal Failure: A Case Report \\ Hamad Dheir ${ }^{1}$, Serap Üngan ${ }^{2}$, Ahmed Bilal Genç ${ }^{2}$, Necattin Firat ${ }^{3}$, \\ Selçuk Yaylacı' ${ }^{2}$, Savaş Sipahi' ${ }^{1}$ \\ ${ }^{1}$ Sakarya Üniversitesi Eğitim Ve Araştırma Hastanesi Nefroloji Bilim Dalı \\ ${ }^{2}$ Sakarya Üniversitesi Eğitim ve Araştırma Hastanesi İç Hastalıkları Ana Bilim Dalı \\ ${ }^{3}$ Sakarya Üniversitesi Ĕğitim ve Araştırma Hastanesi Genel Cerrahi Ana Bilim Dalı
}

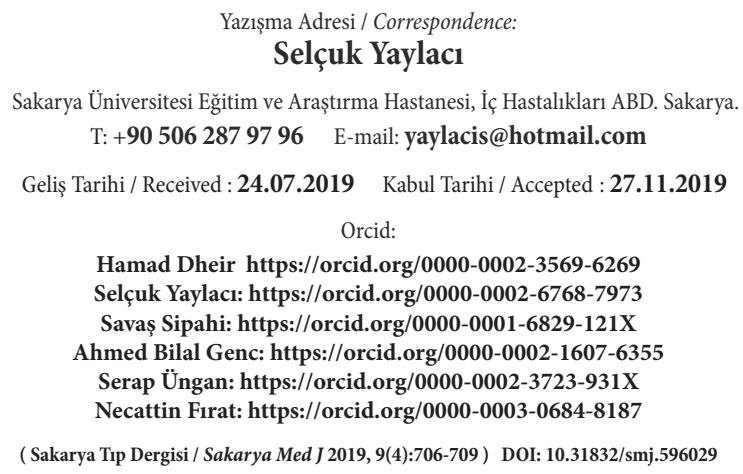

$\ddot{\mathrm{Öz}}$

Kontrast maddeler akut böbrek hasarının önemli nedenlerinden biridir. Son zamanlarda, manyetik rezonans görüntüleme (MRG) incelemeleri için kullanılan gadolinyum bazlı kontrast maddenin (Gd-KM) akut böbrek hasarını $(\mathrm{ABH})$ indüklediği bildirilmeye başlanmıştır. Bu yazıda sistemik hastalı̆̆ı ve hiçbir risk faktörü olmayan 44 yaş bayan hasta, batın MRG sonrası ABH gelişimesi nedeniyle bildirilmesi amaçlandı.

Anahtar Gadolinyum; Akut böbrek hasarr; Manyetik rezonans görüntüleme

kelimeler

Abstract

Contrast agents are one of the major causes of acute kidney injury. Recently, it has been reported that gadolinium-based contrast agent (Gd-KM) used for magnetic resonance imaging (MRI) induces acute kidney injury (AKI). In this article, we wanted to report a 44-year-old female patient who developed AKI after abdominal MRI without any systemic disease and risk factors.

Keywords Gadolinium; Acute Kidney Injury; Magnetic Resonance Imaging 


\section{GIIRIŞ}

Kontrast maddeler, hastanede yatan hastalarda gelişen akut böbrek hasarın $(\mathrm{ABH})$ üçüncü büyük nedenidir. Gd-KM, manyetik rezonans görüntülemelerde (MRG) birçok hastalığın teşhisi için önem arz etmektedir. Gd-KM; iyodinli kontrast maddelere alternatif olarak kullanılan nefrotoksik olmayan ajanlar olarak bilinirdi. Yaklaşı 13 yıl önce GdKM ile nefrojenik sistemik fibrozis (NSF) arasındaki ilişki tanımlanmıştır. ${ }^{1}$ Son zamanlarda Gd-KM'ye bağlı $\mathrm{ABH}$ bildirilmeye başlanmış. ${ }^{2}$ Chien CC ve ark. tarafından yapılan çalışmada Gd-KM kullandıktan sonra \%10'luk e-GFR (Tahmini glomerüler filtrasyon hızı) düşüş oranı \%16.5 saptanmış. ${ }^{2}$ Renal arter stent yerleştirme işlemi sırasında Gd-KM’e bağlı akut böbrek hasarı insidansı \%14.7 saptanmıştır. ${ }^{3}$ Bu nedenle Gd-KM'nın kullanımı, e-GFR değerine göre böbrek fonksiyon bozukluğu olan hastalarda kullanılmaması yönünde rehberlerde yer almaya başlamıştır., Yüksek doza ( $\geq 0.3 \mathrm{mmol} / \mathrm{kg}$ ) bağlı gelişen Gd-KM nefropati risk faktörleri olarak böbrek disfonksiyonu, diyabetes mellitus, hipertansiyon, koroner arter hastalığ yer almaktadir. ${ }^{6}$

$\mathrm{Bu}$ yazıda bilinen sistemik hastalığı olmayan ve herhangi bir Gd-KM nefrotoksiste risk faktörü taşımayan olgunun sonuçları sunulmuştur.

\section{OLGU}

44 yaşında bayan hasta, bilinen sistemik hastalığı yoktu. 22 Mayıs 2019 tarihinde karın sağ üst kadranda şiddetli ağrısı ve bulantı şikayetleri nedeniyle acil servisimizde bakılan tetkiklerinde üre: $24 \mathrm{mg} / \mathrm{dl}$, kreatinin: $0.7 \mathrm{mg} / \mathrm{dl}$, Aspartat aminotrasferaz: $204 \mathrm{U} / \mathrm{L}$, Alanin aminotransferaz: 140 U/L, safra kesesi taşı saptanmış. Diğer biyokimyasal parametrelerinde herhangi bir patoloji saptanmamış. İnflamatuvar parametreleri normal olan hastaya kolesistektomi operasyonu yapılmış. Kolesistektomi sonrası karaciğer fonksiyon testleri yüksek kaldığı için godalinyum içeren kontrastlı batın MRG çekildikten 3 gün sonra bakılan üre: $62 \mathrm{mg} / \mathrm{dl}$, kreatinin $3.4 \mathrm{mg} / \mathrm{dl}$ saptanmış. Hastaya parenteral hidrasyonu başlanmış. İzleminde iki hafta içinde serum kreatinin değeri $1.57 \mathrm{mg} /$ dl'ye kadar gerilemesi üzerine taburcu edilmiş. 23.07.2019 tarihli kreatinin değeri: 0.7 mg/ dl olarak değerlendirildi.

\section{TARTIŞMA}

Son zamanlarda gadolinyum kontrast maddeye bağlı akut böbrek hasarı sık bildirilmeye başlanmıştır. Özellikle yüksek risk grubu hastalarda anjiografik incelemelerde yüksek doz gadolinyum kullanıldığında $\mathrm{ABH}$ gelişme riski oldukça yüksektir. Bizim olgumuz diyabetes mellitus, hipertansiyon, kronik böbrek hasarı, sepsis veya koroner arter hastalığı gibi herhangi bir risk faktörü taşımamasına rağmen $0.2 \mathrm{mmol} / \mathrm{kg}^{\prime} l \mathrm{k}$ Gd-KM kullanımından sonra ciddi non-oligürik akut böbrek hasarı geliştiği saptadık. $\mathrm{ABH}$; ilk 48 saat içinde serum kreatinin değerinde bazal değerlere göre $\geq 0.3 \mathrm{mg} / \mathrm{dl}$ artış ve idrar çıkışında $\leq 0.5 \mathrm{ml} /$ kg azalma olarak tanımlanmaktadır. ${ }^{7}$ Bizim olguda GdKM uyguladıktan 3 gün sonra bakılan serum kreatinin değeri bazala göre 6 kattan fazla artış saptanmış. Kreatinin artışının etiyolojisinde Gd-KM dışında herhangi bir etiyolojik faktör saptanmamıştır. Gadolinyumun nasıl akut böbrek hasarı geliştirdiği hayvan çalışmalarında gösterilmiştir. Tarvahartiala'nın yaptığı çalışmalarda gadolinyum renal tübülerinde akut tübüler nekroza ve sitoplazmik vakuolizasyona neden olduğu bildirmiştir. ${ }^{8}$ Bu renal tübüler hasarın temel nedeni; gadolinyum insan plazmasına göre hiperosmotik olması nedeniyle tübüllerden geçememesi ve bunun sonucunda serbest oksijen radikallerin salınması, vasodilatatör mediyatörlerin salınımının azalması ve renal kan akımı azalmasına neden olmasıdır. Bu mekanizma, iyodinli hipertonik kontrast maddelerin nefrotoksisite yapma özelliğine benzemektedir. ${ }^{9}$ Biyopsi bazlı bir olguda gadolinyuma bağlı global skleroz, tübüler atrofi ve interstisiyel fibrozis gibi kalıcı hasar geliştiği gösterilmiş. ${ }^{10}$ Gadolinyuma bağlı nefrotoksisite riski; kontrast maddenin total doz miktarına bağlı olabileceği vurgulanmıştır. ${ }^{11}$ Haustein ve ark. tarafından gadolinyum dozu ile nefrotoksik etki bağlantısı araştırılmış, 199 hastayı kapsayan bu çalışmada; $0.1 \mathrm{mmol} / \mathrm{kg}$ ile $0.3 \mathrm{mmol} / \mathrm{kg}^{\prime} \mathrm{l} \mathrm{k}$ gadolinyum dozları arasında herhangi bir nefrotoksisite rastlanmamıştır. ${ }^{12}$ Benzer 
şekilde başka retrospektif bir çalışmada; $0.2 \mathrm{mmol} / \mathrm{kg}-0.4$ $\mathrm{mmol} / \mathrm{kg}^{\prime} \mathrm{l}$ k gadolinyum ile aortik,pelvik veya renal arter MR anjiografi sonrasında herhangi bir böbrek disfonksiyonu saptanmamışırı. ${ }^{13}$ Ancak, bazal serum kreatinin seviyeleri yüksek olan hastalarda gadolinyuma bağlı $\mathrm{ABH}$ gelişme riski gösterilmiş. Sam ve ark.nın 260 hastayı kapsayan çalışmasında, en az $0.25 \mathrm{mmol} / \mathrm{kg}^{\prime} \mathrm{l}$ k gadolinyum uygulandıktan sonra, bazal serum kreatinin değeri normal olan hastalarda $\mathrm{ABH}$ gelişmezken bazal serum kreatinin değeri yüksek olan hastalarda $\mathrm{ABH}$ geliştiği gösterilmiş. ${ }^{14}$ Sonuç olarak, özellikle böbrek disfonksiyonu, sepsis ve diyabetes mellitus öyküsü olan hastalarda düşük doz gadolinyum kontrast maddesi dikkatle kullanılabilir. Ancak, $\geq 0.4 \mathrm{mmol} / \mathrm{kg}$ 'lık yüksek doz gadolinyum kullanılması nefrotoksisite açısından potansiyel risklidir. 
Sakarya Tip Dergisi 2019;9(4):706-709

\section{Kaynaklar}

1. Marckmann P, Skov L, Rossen K, Dupont A, Damholt MB, Heaf JG, et al. Nephrogenic Systemic Fibrosis: Suspected Causative Role of Gadodiamide Used for Contrast-Enhanced Magnetic Resonance Imaging. J Am Soc Nephrol 2006;17:2359-62. doi:10.1681/ ASN.2006060601.

2. Chien C-C, Wang H-Y, Wang J-J, Kan W-C, Chien T-W, Lin C-Y, et al. Risk of Acute Kidney Injury after Exposure to Gadolinium-Based Contrast in Patients with Renal Impairment. Ren Fail 2011;33:758-64. doi:10.3109/0886022X.2011.599911.

3. Takahashi EA, Kallmes DF, Mara KC, Harmsen WS, Misra S. Nephrotoxicity of gadolinium-based contrast in the setting of renal artery intervention: retrospective analysis with 10-year follow-up. Diagn Interv Radiol 2018;24:378-84. doi:10.5152/dir.2018.18172.

4. Schieda N, Maralani PJ, Hurrell C, Tsampalieros AK, Hiremath S. Updated Clinical Practice Guideline on Use of Gadolinium-Based Contrast Agents in Kidney Disease Issued by the Canadian Association of Radiologists. Can Assoc Radiol J 2019. doi:10.1016/j. carj.2019.04.001.

5. Perazella MA. Gadolinium-contrast toxicity in patients with kidney disease: nephrotoxicity and nephrogenic systemic fibrosis. Curr Drug Saf 2008;3:67-75. http://www.ncbi.nlm.nih. gov/pubmed/18690983. Accessed 21 Jul 2019.

6. Fujisaki K, Ono-Fujisaki A, Kura-Nakamura N, Komune N, Hirakawa N, Tsuruya K, et al. Rapid deterioration of renal insufficiency after magnetic resonance imaging with gadolinium-based contrast agent. Clin Nephrol 2011;75:251-4. doi:10.5414/cnp75251.

7. Khwaja A. KDIGO Clinical Practice Guidelines for Acute Kidney Injury. Nephron 2012;120:c179-84. doi:10.1159/000339789.
8. Tervahartiala P. Contrast media-induced renal tubular vacuolization after dehydration. A light and electron microscopic study in rats. Invest Radiol 1992;27:114-8. http://www.ncbi. nlm.nih.gov/pubmed/1601601. Accessed 21 Jul 2019.

9. Tumlin J, Stacul F, Adam A, Becker CR, Davidson C, Lameire N, et al. Pathophysiology of contrast-induced nephropathy. Am J Cardiol 2006;98:14K-20K. doi:10.1016/j.amjcard.2006.01.020.

10. Akgun H, Gonlusen G, Cartwright J, Suki WN, Truong LD. Are gadolinium-based contrast media nephrotoxic? A renal biopsy study. Arch Pathol Lab Med 2006;130:1354-7. doi:10.1043/1543-2165(2006)130[1354:AGCMNA]2.0.CO;2.

11. Boyden TF, Gurm HS. Does gadolinium-based angiography protect against contrast-induced nephropathy?: a systematic review of the literature. Catheter Cardiovasc Interv 2008;71:687-93. doi:10.1002/ccd.21459.

12. Haustein J, Laniado M, Niendorf HP, Louton T, Beck W, Planitzer J, et al. Triple-dose versus standard-dose gadopentetate dimeglumine: a randomized study in 199 patients. Radiology 1993;186:855-60. doi:10.1148/radiology.186.3.8430199.

13. Prince MR, Arnoldus C, Frisoli JK. Nephrotoxicity of high-dose gadolinium compared with iodinated contrast. J Magn Reson Imaging 6:162-6. http://www.ncbi.nlm.nih.gov/pubmed/8851422. Accessed 21 Jul 2019.

14. Sam AD, Morasch MD, Collins J, Song G, Chen R, Pereles FS. Safety of gadolinium contrast angiography in patients with chronic renal insufficiency. J Vasc Surg 2003;38:313-8. http:// www.ncbi.nlm.nih.gov/pubmed/12891113. Accessed 21 Jul 2019. 